\title{
FACILITATORS' PERCEPTIONS OF PROBLEM-BASED LEARNING AND COMMUNITY-BASED EDUCATION
}

\author{
Annali E Fichardt \\ D.Ph.D, \\ Programme Director: Postgraduate Studies, \\ School of Nursing \\ UOFS
}

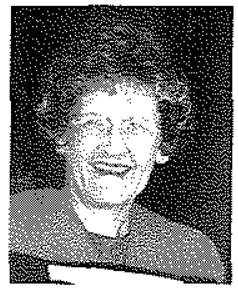

Paula P du Rand
Ph.D, Senior Lecturer,
School of Nursing,
Faculty of Health Sciences
UOFS

\begin{abstract}
In 1997 the School for Nursing, University of the Orange Free State, changed from the traditional lecture method of teaching to problem-based learning and from a curative to a community-based approach. Lecturers from a traditional environment became facilitators and new skills such as listening, dialogue, negotiation, counselling and problemsolving were expected from them. Besides the role change, the environment changed from a structural classroom to an unstructured community. The aim of this research was to determine the perceptions and experiences of facilitators in problem-based learning and community-based education. In this explorative and descriptive study a qualitative design was followed. The study population of ten first and second year facilitators were included in the research. Data was collected by means of two focus groups by an independent person. Focus groups were tape recorded and content analysis was done. Facilitators identified problems and needs, but positive aspects of the new teaching methodology were also emphasised. The research showed that a paradigm shift from the traditional teaching method to an innovative method leads to distinctive problems and makes more demands on facilitators. The re-education and continuous support of academic staff are essential for a problem-based learning and community-based education programme.
\end{abstract}

\section{OPSOMMING}

In 1997 het die Skool vir Verpleegkunde, Universiteit van die Oranje-Vrystaat, van 'n tradisionele lesingmetode na probleemgebaseerde leer en van 'n kuratiewe na 'n gemeenskapsgebaseerde benadering verander. Lektore vanuit die tradisionele benadering is as fasiliteerders aangewend en nuwe vaardighede soos luister, dialoog, onderhandeling, berading en probleemoplossing is van hulle vereis. Benewens die rolverandering, het die omgewing vanaf ' $n$ gestruktureerde lesinglokaal na die ongestruktureerde gemeenskap verander. Die doel van hierdie navorsing was om die persepsies van fasiliteerders in probleemgebaseerde leer en gemeenskapsgebaseerde onderrig te bepaal. In hierdie verkennende en beskrywende studie is van 'n kwalitatiewe ontwerp gebruik gemaak. Die totale populasie van tien eerste- en tweedejaar fasiliteerders is by die studie ingesluit. Data is versamel deur middel van twee fokusgroeponderhoude deur 'n onafhanklike persoon. Die fokusgroeponderhoude is op band opgeneem en inhoudsanalise is gedoen. Die fasiliteerders het probleme en behoeftes geidentifiseer, maar positiewe aspekte van die nuwe onderrig metodologie is ook beklemtoon. Die navorsing het aangetoon dat die paradigma verskuiwing vanaf die tradisionele onderrigmetode na 'n innoverende onderrigmetode tot bepaalde probleme lei en meer vereistes aan fasiliteerders stel. Die heropleiding en volgehoue ondersteuning van akademiese personeel is essensieël vir ' $n$ probleemgebaseerde leer en gemeenskapsgebaseerde onderrigprogram.

\section{INTRODUCTION}

For a long time authors have voiced concern about the education of health care workers (Neame, 1984:699). The need for change was certainly augmented by the powerful global movement towards "Health for All by the Year 2000" and the necessity to reorientate national health care delivery systems toward primary care to serve that goal (WHO Alma Ata, 1978). Almost simultaneously a concept of integrated health services and manpower development emerged, which indicated that the quantity and quality of health manpower had to be planned in response to specific needs of the national health system and through this, to the health needs of the population (WHO, 1978). The role of health professions education institutions in this process became clear. In an "Agenda for Action" the Universities are challenged to prepare health professionals for the prospective needs and demands of society (WHO Agenda for Action, 1991).

In South Africa, the new government emphasise the Primary Health Care Approach as the means to improve and maintain the health of the South African population (Official Policy Document issued by the Department of Health, 1996:5). The delivery of a comprehensive, high quality primary health care service is, however, restrained by substantial gaps in both the quality and quantity of suitably trained primary health care nurses, doctors, other paramedical staff and managers. The 
strengthening of the human resources capacity of primary health care facilities is thus a central component of the health care services.

At the beginning of 1996 the National Commission on Higher Education made recommendations in a working document that health education institutions revise their curricula in order to equip health care students and health personnel educators with the knowledge, competency and attitudes comprehensively to respond to the health care needs of the population of South Africa. It also recommended that higher education should play specific roles in the fields of continuing education for professional health care personnel and should ensure the relevance of courses to the health needs of the population, in order to produce appropriately skilled and orientated persons for the national health care services (National Commission on Higher Education, 1996).

The call for change in the education of professional practioners caused the School of Nursing, University of the Orange Free State to reflect on their programmes.

In 1997 the School of Nursing changed from the traditional lecture method of instruction to problembased learning and from a curative to a communitybased education approach. Problem-based learning (PBL) is seen as an instructional method characterised by the use of patient problems as a context for students to learn problem-solving skills and acquire knowledge, in a small group with a facilitator (Fichardt, 1996:59). Community-based education is a means of achieving educational relevance to community needs. The community is extensively used as a learning environment and the students, teachers and community are engaged throughout the educational experience (WHO, 1985:1)

\section{PROBLEM STATEMENT}

The role of the facilitator in an innovative programme is a rather critical one (Pallie \& Carr, 1987:65). According to Barrows (1986:9) facilitators are an unplanned variable and this has a effect on the quality of education programmes. The facilitator is pivotal and actively coordinates the group and the process of learning. According to Bailey (1991:987) the facilitator does not primarily need subject expertise but the skills of listening, dialogue, negotiation and counselling.

However, the role of facilitating discussion rather than directing it, is foreign and even "good" teachers have difficulty adopting this new approach (Albanese \& Mitchell, 1993:74).

Although facilitators in the School of Nursing, University of the Orange Free State, attended several international and national conferences and workshops, as well as training sessions in the School of Nursing on the role of facilitators and the process of facilitation, it became evident that the role change from lecturer, from a traditional teaching environment, to facilitator leads to anxiety, uncertainties and frustrations. These feelings were enhanced by the environmental change in which learning had to take place, the change from a structural classroom to an unstructured community.

\section{AIM}

The aim of this research was to determine the perceptions of facilitators in the problem-based learning and community-based education undergraduate programme of the School of Nursing of the University of the Orange Free State.

The objectives were to:

- ascertain the problems of facilitators in PBL and CBE;

- determine the needs of facilitators in PBL and $\mathrm{CBE}$; and

- make recommendations regarding the preparation and future support of facilitators in PBL and CBE.

\section{RESEARCH DESIGN}

In this explorative and descriptive study a qualitative design was used and the research was contextual in nature. Focus group interviews were conducted with facilitators of first and second year students. All the facilitators agreed and were eager to participate.

\section{SAMPLE}

The study population was the facilitators of first and second year students of the School of Nursing of the University of the Orange Free State. The total population of ten facilitators was included in the study.

\section{ETHICAL CONSIDERATIONS}

The Ethical Committee, Faculty of Health Sciences of the University of the Orange Free State approved the research. The facilitators were briefed in such a way that they understood the aim of the research. All of them consented orally to participate as they felt a need to discuss facilitation.

Confidentiality was ensured by not linking inputs to individuals. The interviews were conducted in private and all participants were aware of their freedom to disclose information.

\section{DATA COLLECTION}

Data was collected by means of focus groups because, according to Krueger (1994:3), this method is preeminently effective in gaining insight into people's opinions in order to design guidelines. 
Two focus group were conducted: one with the first year facilitators and one with those working with the second year students.

The aim of the focus groups was explained to the facilitators and they were also provided with the following information:

- date and duration of focus groups,

- $\quad$ assurance of confidentiality and

- nature of the follow-up group after data analysis.

An expert in the facilitation of focus groups was approached beforehand to act as focus group facilitator. In this case it was a psychiatric nurse specialist who was skilled and experienced in focus group management. This person met the criteria of a focus group facilitator set by Krueger (1994:102) and Morse (1994:229). The researchers acted as assistants to the group facilitator and took field notes.

A room with comfortable chairs arranged around a table was reserved for the focus groups. Two tape recorders were set up and each session lasted an hour and a half.

Only one open ended question was asked to enable the facilitators to share personal thoughts, perceptions and feelings in an unstructured manner.

The question was:

"What are the problems/challenges and needs you have experienced during your role as facilitator to students in PBL and CBE?"

The facilitator led the focus groups and introduced the discussions. She also evoked questions about aspects requiring in-depth treatment. Discussions focused on relevant areas in an indirect way and the facilitator made sure that important questions were raised. Participation by the group facilitator was minimal although the respondents were encouraged to discuss their feelings without being pressurised by the situation (Kamfer, 1989:7).

The researchers transcribed the tapes to prepare for data analysis.

The researchers, who acted as assistants, documented the group process and dynamics during the focus groups. Afterwards the group facilitator compared her observations with those of the researchers.

\section{RELIABILITY AND VALIDITY OF DATA ANALYSIS}

\section{Trustworthiness}

According to Krefting (1991:219) cross-examination is a strategy to ensure trustworthiness. This was done by having the researchers present at focus group sessions as assistants to the group facilitator. Sound recordings were made and field notes taken. After completion the categories, groups and themes were discussed and confirmed or amplified with the respondents at a follow-up group.

\section{Applicability (transferability)}

Krefting (1991:220) states that qualitative contextual research cannot be generalised because it is so situation-bound and unique. The responsibility for transferability does not, therefore, rest with the researchers. There is, however, sufficient data accessible in the report for other researchers to judge the transferability should they so wish.

\section{Consistency}

The researchers preserved all recordings, notes and forms used in order to ensure that the research may be audited and to enhance consistency.

\section{Neutrality}

Neutrality refers to the degree to which research findings reflect the actual facts of the research and are not influenced by other parties, motivations or perceptions (Guba, 1998:80).

An independent person acted as group facilitator as she was not involved in the research at all except for her facilitation of the focus groups.

\section{Choice of participants}

Specific participants were not selected because, according to Kingry, Tiedje and Friedman (1990:124) the homogeneity of a focus group is important. All the respondents participated voluntarily.

\section{Observation effects}

These occur

- when the participants suppress or distort data to make it appear acceptable because they are being observed;

- the researcher interprets and presents data as a result of his/her own position (Woods \& Catanzaro, 1988:137).

To prevent the above the aim of and need for the research were explained to the facilitators. Furthermore the researchers made sure that an independent theoretical analysis and cross-examination by the analysts showed up erroneous responses.

\section{DATA ANALYSIS}

The data was analysed by means of a combination of Kerlinger's (1986:477-483) method and Giorgi's (as 
quoted by Omery, 1983:57-58) basic steps of content analysis.

- The total experience (transcription) was described. This included all verbal responses given by respondents in terms of the central question that was posed. This was re-read to obtain a complete picture.

- The transcriptions were read a second time. Summaries were identified in order to build them up to a whole.

- The analysts eliminated superfluous data in the units and used clearances and extensions of remaining units by comparing the units with one another and then with the whole.

- They ensured that the insight of the researcher in the interviews corresponded with the transcriptions.

- Information was arranged in categories, groups and themes according to recurrent trends.
- The final product was submitted to co-coders for criticism and/or acceptance.

\section{RESULTS}

The results of the focus groups will be expressed in terms of categories, groups and themes. As the groups were homogenous, that is, facilitators in a PBL and CBE programme, the data of the two focus groups will be represented together (Kingry et al. 1990:124). The following categories were identified after completion of the content analysis:

Problems and needs of the facilitators regarding:

- Facilitation

- Coordinator

- Students

- Clinical practicals

\begin{tabular}{|c|c|c|}
\hline CATECORY & GROUP & THEME \\
\hline Facilitation & Problems & $\begin{array}{l}\text { - Facilitation structure lacking } \\
\text { - Thought students were disadvantaged due to ignorance } \\
\text { - Wondered if students were given enough information } \\
\text { Students very demanding. Expected to be available after hours as } \\
\text { well } \\
\text { - Students negatively influenced to PBL beforehand by seniors } \\
\text { - Fifficult to move from hospital-based to community-based teaching } \\
\text { - Condlict took place in groups }\end{array}$ \\
\hline & Feelings & 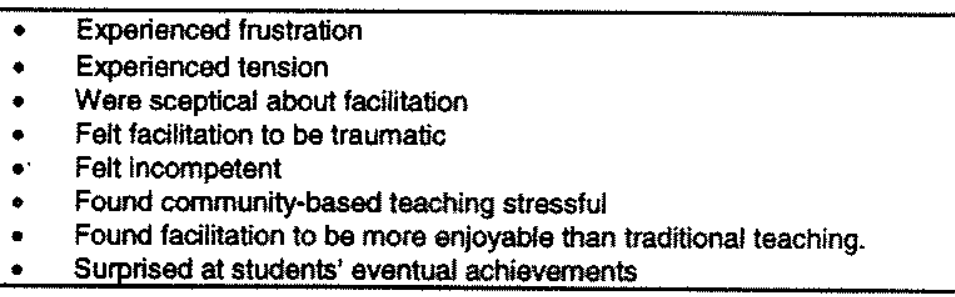 \\
\hline & $\begin{array}{l}\text { Characte- } \\
\text { ilstics of } \\
\text { facilita- } \\
\text { tors }\end{array}$ & $\begin{array}{l}\text { - Must be available to students } \\
\text { - Must have good interpersonal skills } \\
\text { - Must be able to handle criticism } \\
\text { Must be able to share knowledge and experience with co-facilitators }\end{array}$ \\
\hline & & $\begin{array}{l}\text { - Facilitators must support one another } \\
\text { - Must be knowiedgeable about small group management } \\
\text { - Must always be positive } \\
\text { - Must remain professional in dealings with students and the community } \\
\text { Must be able to take the initiative }\end{array}$ \\
\hline & Teaching & $\begin{array}{l}\text { - Theory remains hospital orientated } \\
\text { - Found evaluation problematic } \\
\text { - } \quad \text { Curriculum content still in tems of disciplines } \\
\text { - Textbooks expensive } \\
\text { - } \quad \text { Request a framework to show how to present the work } \\
\text { - Studectives must be avaliable } \\
\text { - PBL and CBT teach students life skills } \\
\text { - Found students to be better equipped than students taught in } \\
\text { - Caditional manner } \\
\text { - Notice and develop potential of students } \\
\text { - Facilitators get back what they put into a group }\end{array}$ \\
\hline
\end{tabular}

*(General, midwivery, psychiatric nursing and community health care)

FIGURE 1: Facilitators' perceptions of facilitation according to groups and themes $(\mathrm{N}=10)$ 


\section{Respondents' problems and needs regarding facilitation}

As summarised in Figure 1 the facilitators singled out certain problems and needs they experienced.

They stated that insufficient structure was provided and that they wondered whether the students obtained adequate information. Students were perceived as being demanding and conflict occurred in groups. They therefore found difficulty in moving from traditional hospital-based teaching to a community-based educational milieu.

Negative feelings such as frustration, tension, incompetence and scepticism were identified.

All the characteristics of a facilitator are represented in Figure 1. Facilitators must also be able to support one another and take the initiative.

One aspect highlighted under teaching was that facilitators wanted a framework indicating how to present the work. They also felt that objectives should be available. It is clear that the facilitators felt a need for structure. Neame (1981:86) also advised that facilitators should be provided with a guide which outlines the problem structure and flow. Several positive aspects were mentioned under teaching, for instance that they found that their students were better equipped than students who were taught conventionally. One facilitator remarked: "You get back what you put into a group".

\section{Respondents' problems and needs regarding the coordinator}

It is important in PBL and CBE to have one person taking responsibility for the coordination of all the various aspects of teaching for every year.
The facilitators were fully aware of the fact the coordinating is not an easy process. To have all the facilitators working together towards a common goal should be a challenge to the coordinator. It appeared that a coordinator must have good communication skills, be approachable and support facilitators. Problems with co-ordination and the characteristics of a co-ordinator as perceived by the facilitators are summarised in Figure 2.

Respondents' problems and needs regarding students

As illustrated in Figure 3 a number of problems relating to students were identified.

It was found that seniors had a negative influence on the perceptions of the students of PBL and CBE. The following response was made:

"When something goes wrong students attribute it to $P B L$ and $C B E$ ". Students also wondered whether PBL and $C B E$ enjoyed international status. Some of the problems among the students may be illustrated by the following observation by a facilitator: "Students are negative because they were not well prepared for $P B L$ and $C B E$ ".

Respondents' problems and needs regarding clinical practicals

Facilitators remarked on the hospital and the community. The only negative aspect in the hospital appeared to be the fact that the facilitators felt that the ward sisters were not informed about PBL. However, the sisters had a positive perception of the students as indicated by the following responses: "The sisters are satisfied with the students". "Students are empathic towards patients".

In the community the facilitators found that the students became frustrated and that it was difficult to apply the principles of practical procedures in that milieu. Negativity was experienced in the community and it was difficult to find learning opportunities. However,

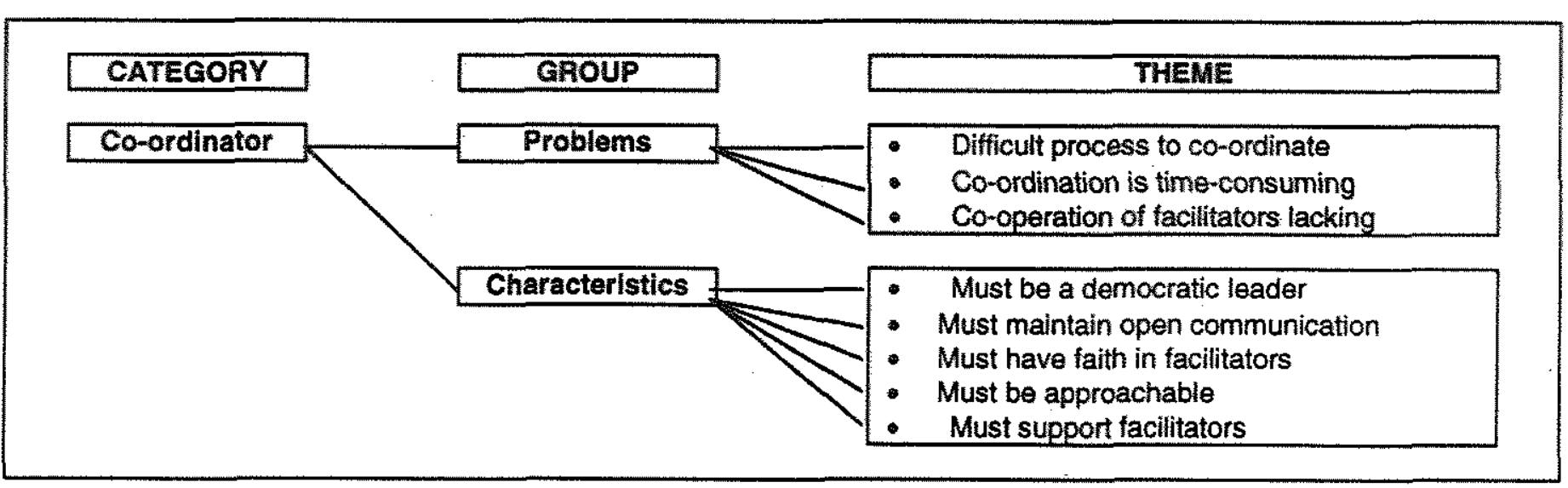

FIGURE 2: Facilitators' perceptions of the co-ordinator according to groups and themes $(\mathrm{N}=12)$ 


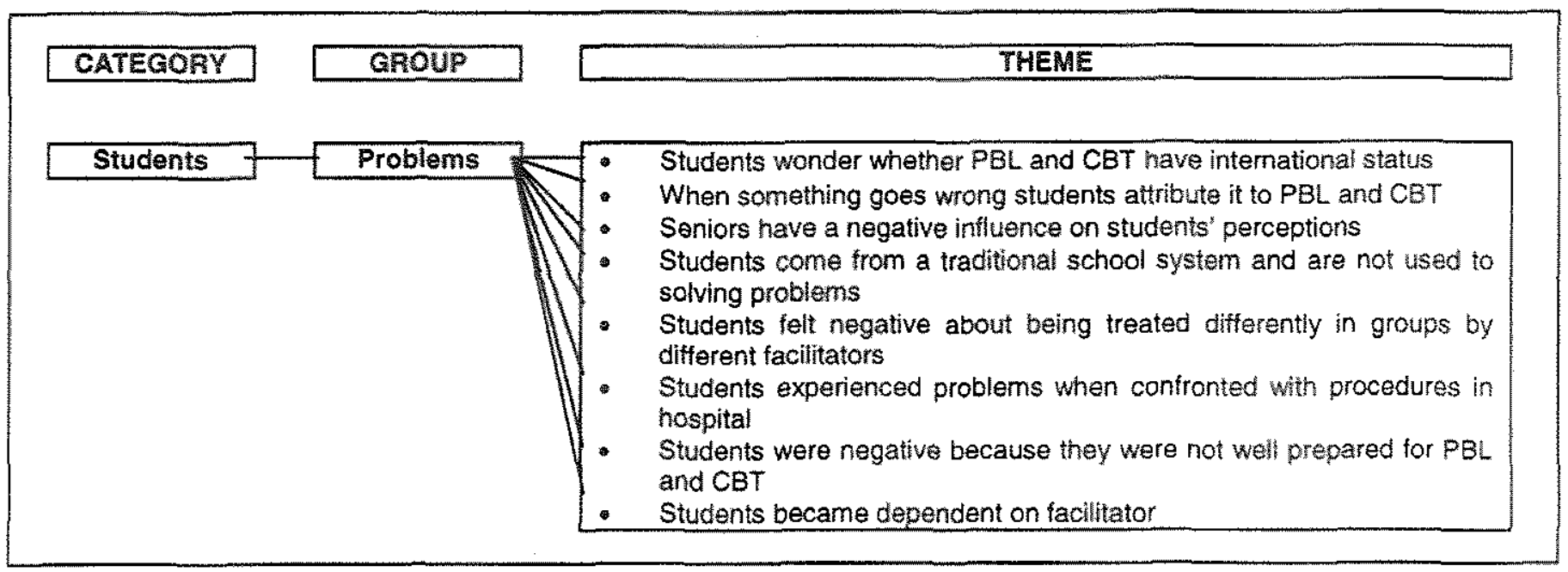

FIGURE 3: Facilitators' perceptions of students according to groups and themes.

the facilitators found that the "people" appreciated the students.

Although problems were identified as shown in Figure 4 under the group "community", the following positive response was recorded: "Community-based teaching was exciting".

\section{CONCLUSIONS}

The data indicates that the facilitators had problems with structuring the learning method. The fact that they were no longer faced with passive students but that their teaching was questioned was experienced as a problem. The paradigm shift from hospital to community-based education led to feelings of uncertainty among the facilitators. The adjustments required gave rise to negative feelings.
The coordination of PBL and CBE was perceived to be comprehensive. The greatest problem was perceived to be the fact that neither the students nor clinical practice were sufficiently well prepared.

Facilitators should have certain characteristics, such as presented in Figure 1, to meet the demands of PBL and CBE. They also have certain needs that must be met. Interpersonal skills and support play an important role in this regard. The need was identified for a coordinator who acts as a democratic leader.

Re-education of academic staff must take place before PBL and CBE commence. Support of facilitators should be a continuing process.

Certain aspects of the data were identified that could promote the facilitation process in PBL and CBE. The

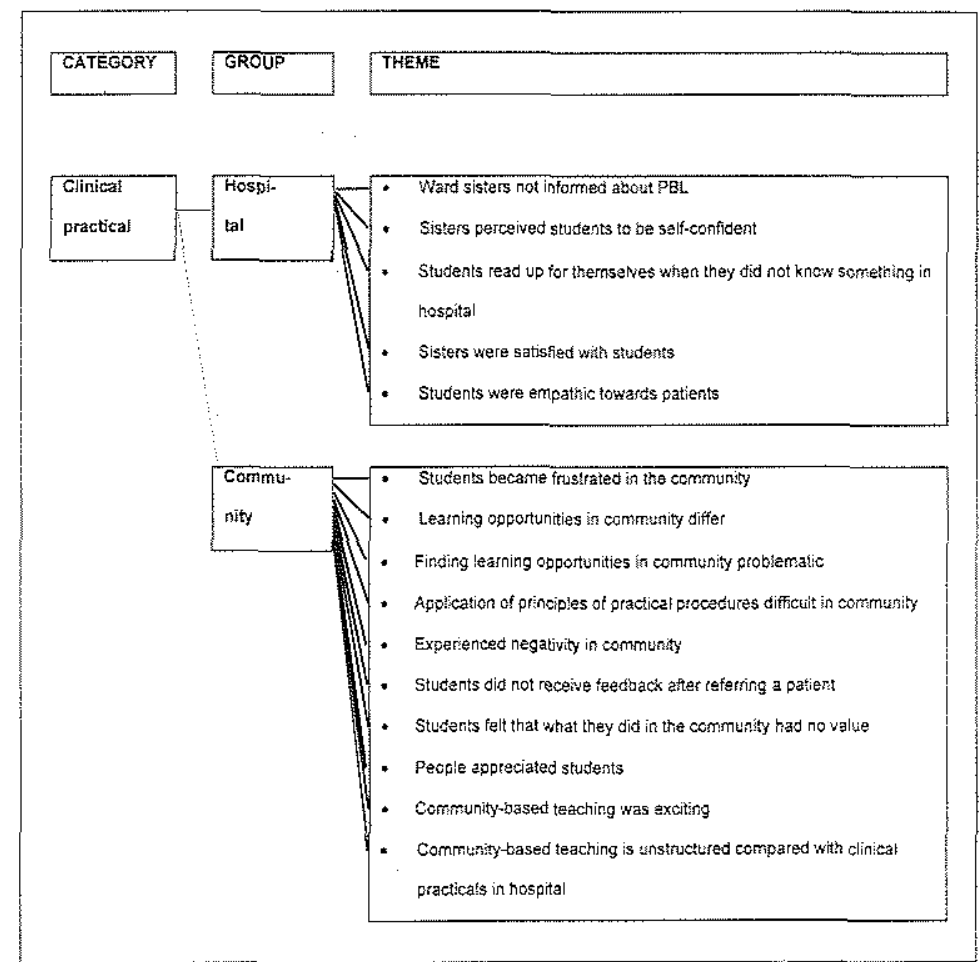

FIGURE 4: Facilitators' perceptions of clinical practicals according to groups and themes 
researchers singled these out in the following recommendations:

\section{RECOMMENDATIONS}

\section{Facilitation}

- To obtain facilitators of the type required for an innovative learning programme, academic staff responsive to the role should be recruited and should undergo careful, in-depth training. This in-depth training should include aspects such as theoretical aspects and skills of facilitation of $\mathrm{PBL}$ and $\mathrm{CBE}$, interpersonal skills and the steps by which communities are explored and access is obtained (Kaufmann, 1994:179-183).

- To help train new facilitators a co-facilitator programme where an inexperienced facilitator cofacilitated a group with an experienced facilitator should be introduced. Pallie and Carr (1987:66) support this co-facilitator training programme.

- Regular group and individual support must be available to facilitators to relieve tension, to identify needs and to address uncertainties and problems.

- Continuing training in all facets of facilitation must be available.

\section{Co-ordinator}

- Whoever acts as coordinator must be selected on the basis of a specific style of leadership and interpersonal skills.

- The coordinator must provide good structure.

- Clinical practicals as well as theoretical aspects must be coordinated.

\section{Students}

- A great deal of emphasis must be placed on the preparation and orientation of students for a $\mathrm{PBL}$ and CBE programme.

\section{Clinical practicals}

- An important factor to ensure the success of a PBL and $\mathrm{CBE}$ programme is thorough preparation of clinical practice for this teaching methodology.

- There must be a contact person available in the community to facilitate and promote liaison and communication.

\section{SUMMARY}

This study was undertaken to describe the perceptions of the facilitators of a PBL and CBE programme. The research showed that a paradigm shift from the traditional teaching method to an innovative method leads to distinctive problems and therefore makes more demands on facilitators. Although the facilitators identified problems and needs, positive aspects of this method were also emphasised. Albanese and Michell (1993:69) also found that the benefits of this teaching methodology overcome the problems. Recommendations were made regarding the preparation and future support of facilitators in PBL and $\mathrm{CBE}$.

Facilitation is generally regarded by facilitators as a continuing learning process.

It has become necessary in higher education to pay more attention to the re-education and support of academic staff to meet the demands of a changed learning environment.

The researchers wish to thank Dr. WJC van Rhyn for conducting the focus groups.

\section{BIBLIOGRAPHY}

ALBANESE, MA \& MITCHELL, S 1993: Problembased learning: A review of literature on its outcomes and implementation issues. Academic Medicine, 61(1):52-81.

BAILEY, D 1991: Facilitator not teacher: A role change for tutors in open learning nursing education. Journal of Advanced Nursing, 17:983-991.

BARROWS, HS 1985 How to design a problem-based curriculum for the preclinical years. New York: Springer.

BARROWS, HS 1986: A taxonomy of problem-based learning methods. Office of Educational Affairs, Southern Illinois University: School of Medicine.

DEPARTMENT OF HEALTH 1996: Restructuring the National Health System for universal primary health care. January 1996.

FICHARDT, AE 1996: A problem-based education programme for registered nurses in advanced midwifery and neonatology. Bloemfontein: UOFS.

KAMFER, L 1989: Focus groups in organizational research. Journal of Industrial Psychology, 15(1):712.

KAUFMANN, KS 1994: The insider/outsider dilemma: Field experience of a white researcher 'getting' in a poor black community. Nursing Research, 43(3): 179-183.

KERLINGER, NF 1986: Foundations of behaviour research. New York: Holt, Rinehart \& Winston. 
KINGRY, MJ; TIEDJE, LB \& FRIEDMAN, LL 1990: Focus groups: A research technique for nursing. Nursing Research, 39(2):124-125.

KREFTING, L 1991: Rigor in qualitative research: The assessment of trustworthiness. The American Journal of Occupational Therapy, 45(3):214-222.

KRUEGER, RA 1994: Focus groups: A practical guide for applied research; 2 nd edition. London: Sage.

MORSE, JM 1994: Critical issues in qualitative research methods. Thousand Oaks: Sage.

NATIONAL COMMISSION ON HIGHER EDUCATION 1996: NCHE health science working and reference group, Task-group five, Working document, A future organisational and financial model for the health sciences, April.

NEAME, RLB 1981: How to construct a problembased course. Medical teacher, 3(3):94-98.

NEAME, RLB 1984: The preclinical course of study: Help or hindrance? Journal Medical Education, 59:699-707.

OMERY, A 1983: Phenomenology: A method for nursing research. Advances in Nursing Science, Jan. $1983,5(2): 49-63$.

PALLIE, W \& CARR, DH 1987: The McMaster Medical Education Philosophy in theory, practice and historical perspective. Medical Teacher, 9(1):59-71.

WHO 1978: Primary health care, Report of the International Conference on Primary Health Care, Alma Ata, USSR. 6-12 September 1978. Geneva: World Health Organisation.

WHO 1991: Changing medical education. An Agenda for Action. Geneva: World Health Organisation.

WHO/EMRO 1978: Report of a ministerial consultation, An integrated approach to health services and manpower development. 26 February - 2 March 1978. Tehran.

WHO 1985: Community-based education by health personnel. Report of a WHO Study Group On Community-Based Education for Health Personnel. Geneva: World Health Organisation.

WILSON, HS 1989: Research in nursing. California: Addison-Wesley Publishing Co.

WOODS, NF \& CATANZARO, M 1988: Nursing research theory and practice. Washington DC: Mosby Co. 